\title{
o Cristianismo moderno de Dom Paulo Arns
}

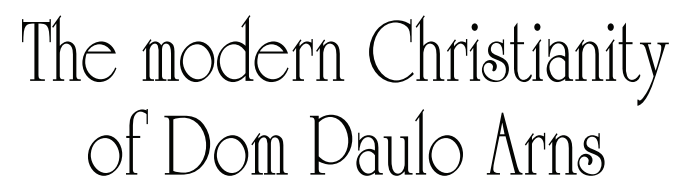

Alex Villas Boas*

Welder Lancieri Marchini ${ }^{* *}$

Resumo: O presente artigo visa apresentar como a atuação pastoral de Dom Paulo Arns na Arquidiocese de São Paulo (1970-1988) estava em sintonia com a mudança de concepção missiológica à partir do Concílio Vaticano II, que não se reduz a uma modernização do catolicismo, mas é fruto de uma hermenêutica de volta as fontes na qual se identifica a capacidade do Evangelho em ser moderno. Para tanto se pretende uma breve explanação da categoria Reino de Deus e as mudanças que sofreu em momentos fundamentais da história.Ao mesmo tempo em que ao ser resgatada como categoria central da evangelização pós-conciliar, o Reino de Deus é também uma chave de leitura fundamental para compreensão da teologia prática do arcebispo da esperança da cidade São Paulo. O modo como a evangelização ligada a ideia de tornar presente o Reino de Deus pode se verificar em alguns de seus principais projetos pastorais, que aqui se pretende apresentar.

Palavras-chave: Dom Paulo Arns, Povo de Deus, Arquidiocese de São Paulo, Teologia Prática.

* Livre docente na Área de Teologia. Professor no Programa de Pós-Graduação em Teologia da PUC PR. Email: alex.boas@pucpr.br

** Doutorando no Programa de Ciências da Religião da Pontifícia Universidade Católica de São Paulo (PUC SP). Email: welder.marchini@gmail.com 
Abstract: The aims of this paper is to present how the Archbishop Paulo Arns pastoral work in the Archdiocese of São Paulo (19701988) was in line with the Second Vatican Council missiological conception, in you ad fonts way. It wasn't just a modernization of Catholicism, but results form a hermeneutic of the Catholic Tradition sources that shows how the Gospel is able to be modern. The central theological category for this view is the Kingdom of God. For the purpose of this paper, it will be a short explanation about the Kingdom of God category and its main changes in key moments in history. This category is a fundamental reading key for undestanding the practical theology of the archbishop of the city of São Paulo, servant of the hope. The way in which evangelization linked to the idea of "making the Kingdom of God present" can take place in some of its main pastoral projects, which this paper intend to present here.

Keywords: Dom Paulo Arns, People of God, Archdiocese of São Paulo, Practical Theology.

\section{Introdução}

O Concílio Vaticano II ressignifica e revisita a semântica teológica da missão na Tradição católica a partir de seu movimento hermenêutico do adfontes, e inicia a superação da ideia de missão que coincide com cristianização que se sustentou e ao mesmo tempo justificou o projeto político e sociológico de Cristandade. A evangelização como concebida no Concílio assumia a tarefa de resgate do anúncio do núcleo do Evagelho, a saber o Reino de Deus revelado por Jesus Cristo em seus gestos e palavras, fonte para toda a sistematização teológica e dinamismo de toda a teologia prática, de onde também Deus se dá a conhecer, na compreensão cristã. Há com isso não uma modernização do catolicismo, apesar de o efeito final parecer ser o mesmo para alguns, mas há a recuperação do Cristianismo e sua capacidade de ser moderno ao apregoar uma boa nova enquanto modo alternativo de viver a cultura (JAEGER, 1991; VAZ, 2002, p. 105-110). 
Tal postura levou a uma dissociação do Reino de Deus com as estruturas políticas de caráter imperial para realocá-la na categoria de Povo de Deus, sujeito político por excelência que reivindica o bem comum e inclui especialmente os que mais precisam em sua opção pelos pobres. Seguindo o espírito e o dinamismo pós-conciliar do magis magisque, conforme concebido por Paulo VI (Ecclesiae Sanctae, 1), de "cada vez mais" adentrar o Cristianismo na sociedade moderna, Dom Paulo Arns parece conceber sua eclesiologia como recepção proativa da Evangelização que tinha como centro o Reino de Deus e a comunidade cristã como consequência pela identificação com o anúncio do modo de vida de Jesus Cristo. Concepção essa que, assim como de Francisco, bispo de Roma, critica a autoreferencialidade eclesial que confunde missão com autopromoção eclesial, quando não hierárquica (Evangelii gaudium, 8).

O Concílio Vaticano II retoma uma categoria central da Tradição cristã que é o Reino de Deus e seu substrato semântico teológico iria, entre outras coisas, criar o neologismo evangelização que aparece pela primeira vez como categoria oficial na semântica da Tradição católica no Concílio Vaticano II re-colocando a centralidade do Reino de Deus no centro da ação eclesial, e ainda identificando-o para além dos limites confessionais. O termo não aparece nem antes de Pio XII, e até mesmo em João XXIII ele está ausente, podendo se dizer que é um termo tipicamente conciliar, pois é nas discussões do Vaticano II que ele é concebido como ressignificação missionária que resgata a compreensão do Reino de Deus no anúncio do Evangelho. ${ }^{1}$ Essa res-

A expressão em âmbito católico aparece por ocasião da I Conferência Geral do Episcopado Latino-Americano, no Rio de Janeiro em 1955, pelo Cardeal Adeodato Piazza, Patriarca de Veneza e enviado de Pio XII para acompanhar a conferência geral, em seu discurso sobre "o problema da evangelização", que incluía em sua preocupação a "educação da juventude, a organização paroquial, a questão social e a assistência aos imigrantes" como problema "missionário e catequético" de "pregar o Evangelho e fazê-lo aceito como doutrina e norma prática de vida" . Em âmbito protestante o uso é mais antigo, aparecendo pela primeira vez no ano de 1900 em Nova York, no Congresso Ecumênico sobre as Missões Estrangeiras, como termo aplicado as preocupações 
Ano XXV • № $90 \bullet$ Jul/Dez 2017

significação da missão, que passa a se chamar Evangelização, já em sua nomenclatura implica uma volta ao anúncio do que o Evangelho proclamava, a saber as narrativas que tratam do kerigma anunciado por Jesus Cristo, que em última instância dizem respeito ao Reino de Deus e, consequentemente, uma postura em relação a vida que implica o reconhecimento da ação do amor de Deus (testemunho), configurador de um estilo de vida marcado pelo signo do amor e disposição do serviço ao mundo (diaconia). ${ }^{2}$

Tal labor não é mero exercício de adaptação de linguagem, mas revisão metanoica, enquanto implica uma mudança de mentalidade que atinge o modo de ser cristão no Mundo, que ao invés de meramente cristianizá-lo por via da expansão institucional, visa a expansão do Reino de Deus, tanto em sua forma confessional cristão, como sabendo reconhecer os sinais do Reino em diferentes confissões religiosas e mesmo em âmbitos não-religiosos.

Tal reconhecimento não é mera adaptação, mas resulta de um itinerário de salvação, que da graça imerecida se faz caminho de fé confiante nesse Amor e abertura para amar e servir como forma de gratidão, especialmente a quem mais precisa, processo que se desdobra na dinâmica da graça-gratidão-gratuidade, implicando não somente um discurso, mas um processo de subjetivação agápica que desdobra no alargamento de uma consciência ética ainda que ciente de sua falibilidade, faz a opção fundamental de humanizar o humano

missionárias em relação ao mundo moderno, de onde emerge também a expressão evangelismo (MELO, 1996: 61-62)

2 Não se encontra anteriormente o termo "evangelizatio" nos escritos papais, como substantivo e suas declinações, como por exemplo "evazelizationis". As traduções em vernáculo que optam pelo uso de "evangelização" nos documentos oficiais do Vaticano anteriores ao período do Concílio, talvez com o intuito de facilitar a compreensão do leitor, não são diretas do termo latino e suas declinações, como é o caso das Cartas Encíclicas de Pio XII, Ad Apostolorum Principis, nn. 3 e 28 (29/06/1958), Le Pèlerinage de Lourdes (02/07/1957), Ecclesiae Fastos (05/06/1954), Evangelii Praecones, nn. 8, 22 e 54 (02/06/1951), Saeculo Exeunte Octavo (13/06/1940) e também em João XXIII, a saber Aeterna Dei Sapientia, nn. 19 e 26 (11/11/1961), Princeps Pastorum, n. 44 (28/11/1959), Sacerdotii Nostri Primordia, n. 57 (01/08/1959). 
por meio da vida de Jesus Cristo. Com isso não nega outras formas de humanização do humano, mas antes reconhece como sinais do Reino de Deus, e quando estas formas todas se unem em prol do humano, melhor se evidencia a dinâmica da graça reúne todo o Povo de Deus. Evangelização, portanto, tem a ver com "tornar o Reino de Deus presente no mundo" (Evagenlii gaudium, 176), de modo que "nenhuma definição parcial e fragmentada, porém, chegará a dar razão da realidade rica, complexa e dinâmica que é a evangelização, a não ser com o risco de a empobrecer e até mesmo de a mutilar”. A evangelização pós-conciliar só é possível de se entender dentro de uma abrangente "visão de conjunto" e "todos os seus elementos essências” (Evangelii nuntiandi, 17), concepção essa que Dom Paulo Arns (1921-2016) parece ter assumido em seu episcopado.

\section{Evangelização do mundo moderno como presença do Reino de Deus}

A teologia conciliar ao recuperar a teologia do Reino de Deus gera a compreensão de que há uma "revelação na práxis” (METZ, 1999, p. 246-255), sendo a tarefa da ressignificação da Tradição cristã em diálogo com o mundo moderno não somente uma adaptação retórica, mas uma verdadeira metanóis, uma mudança de mentalidade no modo de ser, do qual emerge o anúncio da presença de Deus onde Seu Reino se manifesta. A Constituição Dogmática Dei Verbum do Concílio Vaticano II diz que a revelação do Mistério de Deus se dá por meio de "gestos e palavras [gestis verbisque], intimamente relacionadas [connexis] entre si, de tal maneira que as obras, realizadas por Deus na história da salvação, manifestam e confirmam a doutrina e as realidades significadas pelas palavras; e as palavras, por sua vez, declaram as obras e esclarecem o mistério nelas contido" (Dei Verbum, 2).

Deste modo, essa categoria, gesta et verba, indica a pedagogia divina, que por vezes se dá a conhecer claramente (Palavra), mas em outras vezes, se faz conhecer também em Sua eloquente e silenciosa 
presença. Os gestos são categorias que pedem uma contemplação silenciosa, uma atenção cheia de reverência ao Mistério que naquele gesto se esconde. O gesto enquanto forma de Revelação se situa dentro da questão da linguagem teológica que o Vaticano II apresenta como tarefa de revisão do dogmatismo formalista da segunda escolástica, pois “uma coisa é o próprio depósito de fé ou as verdades e outra é o modo de enuncia-las, conservando-se, contudo, o mesmo sentido [sensu] e significado [sententia]" (Gaudium et Spes, 62). Tais termos sensu e sententia remetem ao método teológico de Hugo de São Vitor (1096-1141), no século XII, que é resumido em uma fórmula célebre: littera, sensu, sententia. O método sugere que se apreenda o significado imediato da palavra (sensus), a partir da sua articulação literal (lettera), determinando a interpretação do conteúdo doutrinal. A “lição” [lectio] se torna uma “questão” [questio] (CHENU, 1983: 412), um tema a ser problematizado, criticado, aprofundado, revisitado até alcançar maior profundidade na pedagogia vitoriana, ou seja, de mero conteúdo se desdobra em uma questão problematizada que visa uma “compreensão mais profunda” [profundior intelligentia].

Essa profundidade vitoriana supõe um próprio caminho de crescimento e santidade que começa com o estudo, depois a meditação, a oração e por fim, a ação e só depois desta é que é possível se abrir ao dom da contemplação, onde se atinge a profundidade da intelligentia, ou seja, de ler por dentro [intus legere] do Mistério escondido em meio a questão (latens deitas diria São Tomás de Aquino), o modo de chegar ao melhor juízo [sententia] (Didascalion, III, 9).

0 gesto tal qual a palavra se situa nesse caminho de pensar a melhor ação que permite desvelar o Mistério a ser contemplado, na medida em que é desvendado seu enigma. O gesto imbuído do Espírito do Evangelho é sinal e convite ao aprofundamento da intelecção da pedagogia divina na história, o gesto é um ícone da ação de Deus amorosa. Deste modo, os gestos de Jesus, tal qual Suas palavras são constitutivos do Evangelho, pois é o modo de desvelar a presença 
eloquente e silenciosa de Deus. Nas Escrituras cristãs também não está presente o substantivo "evangelização”, mas o substantivo evangelho (Mt 4,23; Mc 1,1; Lc 8,1; At 13,32 e outros), seu emprego verbal evangelizar (Lc 4,18; At 8,25; Ef 2,17; 1Pd 1,25) e o sujeito da ação como evangelista que escreve/reproduz ou evangelizador que anuncia (At 21,8; Ef 4,11; 2Tm 4,5). Contudo Evangelho se refere sempre a pregação de Jesus, em gestos e palavras que tem como núcleo central o Reino de Deus, como categoria salvífica por excelência, em oposição ao juízo condenatório, como um Reino em que a justiça e a paz são fruto do amor misericordioso de Deus Pai, com especial atenção aos pobres, a ponto de Ele mesmo se fazer pobre (2 Cor 8,9), o sim do Mistério da encarnação se deu por uma jovem pobre, nasceu entre os filhos de pessoas pobres, foi apresentado no Templo como filho de uma família pobre (Lc 2,24), e se apresenta como ungido para anunciar a Boa nova aos pobres (Lc 4,18), dizendo aos que mais sofrem a injustiça que o Reino de Deus a eles pertencem (Lc 6,20), e com eles se identifica ensinando que a misericórdia para com eles é a chave do Reino do Céu (Mt 25,34-40). O pobre enquanto injustiçado é alvo do Reino de Deus e para onde a diaconia daquele que reconhece Jesus como Senhor deve se dirigir preferencialmente, como "forma especial de primado na prática da caridade cristã”, a fim de que os cristãos possuam "os mesmos sentimentos de Cristo" (Fl 2,5 cf. EG 198), da gratidão para com a graça do amor de Deus para a gratuidade com aqueles que com ninguém podem contar e nem retribuir. O Reino de Deus anunciado possui um fator de transformação histórica, no qual aquele se encanta com o anúncio da Misericórdia do Amor do Pai e da Justiça aos que mais precisam devem adotar como escolha de vida e assim servir de sal da terra e luz do mundo (Mt 5,13-14).

Nesse sentido a semântica da evangelização está em continuidade ao ministério dos profetas de anunciar o Reino de Deus, e reconhecer os seus sinais, fruto do Amor de Deus por todos. Em um segundo momento, o termo também incorpora a semântica grega de um anúncio 
de uma experiência de encontro com a pessoa de Jesus Cristo, como caminho mistagógico aos moldes da cultura grega. O Evangelho incorpora tanto a lógica poética das Escrituras Hebraicas e da tradição poética grega na "teologia dos quatro sentidos" [quadriforme ratio] que despertava a sensibilidade para a meditação da palavra [littera] que servia de metáfora viva [analogia] para a vida [moral], provocando um modo de ser que levava a se aproximar do Mistério de Deus [anagogia], quanto a reflexão das escolas filosóficas gregas [logos] em sua ampla capilaridade social e cultural. A dinâmica da graça-gratidão-gratuidade na vida do Povo se desdobra na dinâmica pessoa-comunidade[ecclesia]-sociedade[pólis], de modo que a experiência pessoal ocorre com a aceitação não somente de uma palavra, mas com um itinerário mistagógico no qual ocorre a identificação da pessoa como modo de ser dos cristãos, seguidores de Jesus Cristo, e que assumem para si os problemas sociais de onde habitam, de modo que cristão na cidade [polis]se vê como um cidadão [politai] (Carta $a$ Diogneto 5,5). Neste itinerário está a experiência de confirmação de que o que é anunciado é visto como bom, por seus efeitos e sinais, próprio da tradição literária bíblica e que vincula o tema da iluminação interior que conduz para um agir ético e de transformação, próprio da tradição filosófica cristã (VILLAS BOAS, 2016, p. 270-311).

A expansão do anúncio do Evangelho para a cultura grega nos quatro primeiros séculos promoveram uma ação missionária "metódica”, na qual assimilava a cultura em que se situava, no sentido de que as "razões de sua esperança” passassem a ser a esperança da cultura em que passa a habitar e "didática”, enquanto cuidado de fazer-se compreensível para diferentes culturas e níveis de apropriação (de escravos a pessoas influentes na sociedade), a ponto de o Cristianismo ser considerado uma Paideia alternativa, uma cultura que mergulha no mais profundo da outra cultura, não somente para apropriar do que ela tem de melhor, mas ainda dilatar com a dimensão dinâmizadora da graça [energia] e do Amor de Deus (JAEGER, 1991, 
p. 54). Mantém-se o aspecto transformador de toda a realidade com a missão que nasce do Evangelho.

É com a forma de Cristianismo Imperial que vai se desenvolvendo até o Edito de Tessalônica (380dc) uma outra teologia do Reino de Deus que o equivale ao formato de império, elaborada principalmente por Eusébio de Cesaréia (265-339). Na eclesiologia eusebiana começa a se conceber a ideia de imperador cristão como vigário de Cristo, sendo a própria ideia de império elevada a categoria de "realidade cristã” (HÜNERMANN, 2004, p. 1505-1506; RAMALHO, 2013, p. 181224). 0 impacto da transformação do Cristianismo em Cristandade, que ganhará várias formas ao longo da História, associará a missão uma dimensão política e um papel conferido a Igreja de reguladora moral, que irá destoar da convivência pacífica com a cultura grega.

0 último pontificado que ainda iría defender uma concepção de missão atrelada ao conceito de Cristandade fora o de Pio XII (1876 - 1958). Mesmo dentro do conceito de Cristandade a categoria do Reino de Deus se faz presente, como elemento para o qual a missão se destina, e no caso do último papa antimoderno, tal categoria estava ligado a uma conversão que tinha por objetivo a regeneração da cultura [de Cristandade], como entende ser a tarefa de seu Papado,

Realizar esta obra de regeneração, adaptando os seus meios às modificadas condições dos tempos e às novas necessidades do gênero humano, eis a tarefa essencial e materna da Igreja. Agregação do Evangelho, imposta pelo seu divino fundador, em que se inculca aos homens a verdade, a justiça e a caridade, e o esforço para arraigar nas almas e nas consciências os seus preceitos, eis também o trabalho mais nobre e frutuoso em favor da paz. A grandiosidade de tal missão quase que esmorece os corações daqueles que fazem parte da Igreja militante. Mas o empenhar-se para que seja difundido o reino de Deus, coisa que cada século procurou realizar de vários modos, com diversos meios e não poucas e duras lutas, é um dever imposto a todo aquele que a graça divina arrancou das garras de Satanás e que com o batismo elegeu cidadão daquele reino (Summi Pontificatus, 60). 
Na eclesiologia piana, a "tarefa materna da Igreja” é entendida como uma Mãe que corrige seus filhos dos "erros", para que se mantenham "incontaminados na fé” (Ad Apostolorum Principis, 34) e aos "tremendos perigos" que podem conduzir as "vítimas de ideias erróneas sobre a realidade da natureza humana”. A crise da Cristandade é vista como uma perda de influência da doutrina cristã, por isso lamenta que "nem todos obedecem ao Evangelho", o que leva a presença de "novos perigos que ameaçam o povo cristão" (Miranda Prorsus, 1957) e convoca Cristandade a "voltar aos preceitos do cristianismo [...] se se quiser formar uma sociedade sólida, justa e equitativa” (Meminisse Iuvat, 5), pois, para ele, é a Igreja que possibilita a ordem social, não necessariamente excluindo outras influências, mas estando ela no centro, como reguladora moral:

A Igreja, quando civiliza os povos sob inspiração da religião cristã, não procede como quem corta, lança por terra e extermina uma floresta luxuriante, mas sim, como quem enxerta árvores bravas com qualidades escolhidas, para que elas venham a dar frutos mais saborosos e sazonados (Evangelii Praecones, 55).

Neste aspecto a missão é confundida com cristianização da cultura na medida em que teologia do Reino de Deus é reduzida a estrutura política imperial de Cristandade e a universalidade do Reino é confundida com a presença hegemônica da Igreja Católica.

Apesar de também estar ausente o termo "evangelização" em João XXIII, há duas grandes perspectivas, entre outras que podem ser elencadas em relação ao seu predecessor, que destoam da eclesiologia e missiologia piana, a saber a ideia de maternidade e universalidade do Reino que determinam a concepção do papado joanino. Contra a recusa de uma Cristandade política e uma teodiceia cultural da "época moderna”, João XXIII não segue o caminho de condenação da modernidade e nem de apologia de uma primazia católica, mas apresenta a Igreja como capaz de apresentar e proclamar "uma concepção sempre atual da convivência humana” (Mater et Magistra [MM], 217) 
Na Carta Encíclica Pacem in terris [PT] há uma radical ruptura com o projeto de Cristandade na medida em que a "paz" emerge da nova consciência dos novos tempos da dignidade humana assimilando na linguagem eclesial a gramática dos Direitos Humanos, e acentuando a convivência social marcada pela justiça, caridade, liberdade valores mais universais e afins da "promoção do bem mútuo" (n. 31).

Em João XXIII a universalidade do Reino de Deus deixa de coincidir com a forma de Cristandade e os inerentes privilégios ocidentais, e vai assumindo a promoção do Bem comum, entendido como "conjunto de todas as condições sociais que permitem e favoreçam nos homens o desenvolvimento integral da personalidade" (MM 65), bem como o reconhecimento da convivência pacífica não somente entre os "irmãos e filhos [da Mãe Igreja] espalhados pelo mundo inteiro, mas todos os homens de boa vontade” para se unirem na "tarefa árdua, mas nobilíssima” (MM 219), de promover a dignidade humana, com especial atenção aos mais vulneráveis, como um "avanço da cultura" (MM 45):

todos os membros da sociedade devem participar deste bem comum, embora em grau diverso, segundo as funções que cada cidadão desempenha, seus méritos e condições. Devem, pois, os poderes públicos promover o bem comum em vantagem de todos, sem preferência de pessoas ou grupos, como assevera nosso predecessor, de imortal memória, Leão XIII: "De modo nenhum se deve usar para vantagem de um ou de poucos a autoridade civil constituída para o bem comum de todos".[31] Acontece, no entanto, que, por razões de justiça e eqüidade, devam os poderes públicos ter especial consideração para com membros mais fracos da comunidade, pois se encontram em posição de inferioridade para reivindicar os próprios direitos e prover a seus legítimos interesses (PT 56).

Ao promover a ideia de "avanço cultural" se identifica que a convivência implica reconhecimento de colaboração, e assim muda o tom de condenação do múnus petrino para reconhecer o "vasto campo de 
Ano XXV • № $90 \bullet$ Jul/Dez 2017

colaboração tanto com cristãos separados desta sé apostólica, como com pessoas sem nenhuma fé cristã, nas quais, no entanto, está presente a luz da razão e operante a honradez natural”. Ainda que haja um cuidado com a coerência cristã, incentiva os católicos no que toca as pessoas de outras religiões e mesmo sem fé, para que "mostrem espírito de compreensão desinteresse e disposição a colaborar lealmente na consecução de objetivos bons por natureza, ou que, pelo menos, se possam encaminhar para o bem” (MM 156). Ademais, o Pontífice sabe reconhecer que para o fenômeno das pessoas que se afastam da Igreja, mas ainda "pelo menos em parte, ajustam a sua vida às normas evangélicas” a “explicação está na ruptura entre a fé e a atividade temporal" por parte da comunidade eclesial (MM 151;152).

Dentro desse contexto de "renovação das relações de convivência na verdade, na justiça e no amor” (MM 211) se situa a centralidade do Reino de Deus em João XXIII, bem como sua precedência na ação missionária, sendo semeado nos novos tempos pela busca comum da justiça, pelo testemunho da caridade cristã em sua motivação de gratuidade na mesma busca, primazia e guia de toda verdade cristã:

É sempre verdade a palavra do Divino Mestre: "Buscai em primeiro lugar o reino de Deus e a sua justiça, e todas estas coisas vos serão acrescentadas" (Mt 6,33). Quando se é "luz no Senhor" (Ef 5,8 ), e se caminha como "filhos da luz" (cf. Ef 5,8), apreendem-se melhor as exigências fundamentais da justiça, mesmo nas zonas mais complexas e difíceis da ordem temporal, em que, não raro, os egoísmos individuais, e os de grupo ou de raça, insinuam e espalham espessas névoas. E quando somos animados pela caridade de Cristo, nós conhecemos os laços que nos unem aos outros, e sentimos como próprias as necessidades, os sofrimentos e as alegrias alheias. Por conseguinte, a ação de cada um, qualquer que seja o objeto da mesma e o meio em que se exerce, não pode deixar de ser mais desinteressada, mais vigorosa e mais humana; pois a caridade: "é paciente, é benigna... não busca os seus próprios interesses... não folga com a injustiça, alegra-se com a verdade... tudo espera, tudo suporta” (l Cor 13,4-7) (MM 255). 
A primazia do Reino de Deus na missão como primazia da justiça no espírito da verdade cristã do Mistério da caridade, fonte igualmente de toda misericórdia que reconhece, defende e dinamiza a dignidade humana é a origem seminal do sentido de evangelização no Concílio Vaticano II. O próprio Papa Buono entende que a ressignificação da semântica teológica do Reino de Deus precisa ser ampliada, e inclusive conta com a atuação do laicato para ajudar a Igreja a discernir sua missão nos novos tempos, atento a sua recepção contextual, ou seja, “disposições daqueles a quem serão dirigidos os seus ensinamentos”, tarefa que o Concílio assume como missão:

Depois destas paternais exortações, confiamos, veneráveis irmãos, que não somente as acolhereis com entusiasmo em vós mesmos, mas também estimulareis nossos filhos do clero e do laicato espalhados pelo mundo todo a acolhê-las. Com efeito - se, como está na expectativa de todos, o próximo concílio ecumênico deverá acarretar um grandíssimo incremento da religião católica; se nele ressoará de modo ainda mais solene a "palavra da reino" de que se fala na parábola do semeador (Mt 13,19); se queremos que por meio dele "o Reino de Deus" se consolide e se estenda sempre mais no mundo - o bom êxito de tudo isso dependerá, em grande parte, das disposições daqueles a quem serão dirigidos os seus ensinamentos de verdade, de virtude, de culto público e privado para com Deus, de disciplina, de apostolado missionário (Paenitentiam Agere, 22).

O Concílio aplica ao substrato semântico da Evangelização a própria tarefa hermenêutica conciliar de que "uma coisa é o próprio depósito de fé ou as verdades e outra é o modo de enuncia-las, conservando-se, contudo, o mesmo sentido [sensu] e significado [sententia]" (GS 62). Uma grande novidade da sensibilidade conciliar para aumentar o diálogo e o "vivo intercâmbio" [vivum commercium], no qual a Igreja não só ensina mas também aprende com as diferentes culturas em um tempo "em que tudo muda tão rapidamente e os modos de pensar variam tanto" é contar com a “ajuda” [auxilio] daqueles 
que vivem no mundo [viventes in mundo] [...] sejam eles crentes ou não [sive de credentibus sive de non credentibus]:

Para aumentar este intercâmbio, necessita especialmente a Igreja - sobretudo hoje, em que tudo muda tão rapidamente e os modos de pensar variam tanto - da ajuda daqueles que, vivendo no mundo, conhecem bem o espírito e conteúdo das várias instituições e disciplinas, sejam eles crentes ou não. É dever de todo o Povo de Deus e sobretudo dos pastores e teólogos, com a ajuda do Espírito Santo, saber ouvir, discernir e interpretar as várias linguagens do nosso tempo, e julgá-las à luz da palavra de Deus, de modo que a verdade revelada possa ser cada vez mais intimamente percebida, melhor compreendida e apresentada de um modo conveniente [...] Ao ajudar o mundo e recebendo dele ao mesmo tempo muitas coisas, o único fim da Igreja é o advento do reino de Deus e o estabelecimento da salvação de todo o género humano (GS 44b-45).

Ao resgatar a dimensão evangélica do Reino de Deus para além dos limites cristãos, também resgata o conceito de Povo de Deus que é maior que o conceito de Igreja, enquanto instituição confessional, redimensionando a finalidade eclesial, como "sacramento universal de salvação”, enquanto sinal que ajudar a visibilizar "o mistério do amor de Deus pelos homens” (GS 45). A categoria teológica de Povo de Deus entende que "sinceramente que todos os homens, crentes e não-crentes, devem contribuir para a reta construção do mundo no qual vivem em comum" (GS 21), quer seja o Povo de Deus "por Cristo congregado" (GS 3) quer seja a parcela de "todos os homens de boa vontade, em cujos corações a graça opera ocultamente” (GS 22). Mesmo lamentando o "ateísmo" por dificultar o entendimento da bondade do Criador, que não se opõe a gramática da "dignidade do homem", entende que o "remédio" não está na condenação, pois "só Deus pode responder plenamente e com toda a certeza, Ele que chama o homem a uma reflexão mais profunda e a uma busca mais humilde”, a dor presente nas razões de recusa de Deus, não raro 
ligado a um imaginário de teodiceia, mas "há-de alcançar-se, antes de mais, com o testemunho duma fé viva e adulta, educada de modo a poder perceber claramente e superar as dificuldades”, porém, mais uma vez o Concílio insiste na primazia da caritas sobre a veritas:

Ela [a fé] deve manifestar a sua fecundidade, penetrando toda a vida dos fiéis, mesmo a profana, levando-os à justiça e ao amor, sobretudo para com os necessitados. Finalmente, o que contribui mais que tudo para manifestar a presença de Deus é a caridade fraterna dos fiéis que unânimemente colaboram com a fé do Evangelho (18) e se apresentam como sinal de unidade" (GS 21).

\section{0 Cristianismo moderno de Dom Paulo Arns e sua teologia prática}

O que se chamou aqui de Cristianismo Moderno a partir da mudança da concepção de missão, tendo o Reino de Deus como centro do anúncio do Evangelho e o Povo de Deus como sujeito da missão, se verifica de modo peculiar na teologia prática de Dom Paulo Arns, na Arquidiocese de São Paulo (1970-1988), no qual o dinamismo conciliar de cada vez mais avançar na ressignificação das práticas eclesiais [magis magisque] era traduzido no dinamismo de agir "de esperança em esperança” [ex spe in spem]. A teologia prática de Dom Paulo se concretiza em sua ação pastoral. Seus parâmetros teológicos impulsionam sua prática eclesial. Fernando Altemeyer, teólogo muito próximo de Dom Paulo e presente nas organizações da arquidiocese, diz a respeito de seu episcopado,

sua prioridade de vida eram os pobres e os moradores das periferias, migrantes, trabalhadores, mulheres, jovens, negros e favelados. Assumiu o pastoreio fortalecendo as comunidades eclesiais de base, a luta pelos direitos humanos, a operação periferia e, sobretudo a questão do Mundo do Trabalho (2015, p. 14). 
Nos parágrafos que se seguem traremos três situações que nos auxiliam no entendimento da teologia prática que faz parte da vida episcopal de Dom Paulo. Primeiramente podemos entender que essa teologia nasce de uma sincera postura de diálogo com o meio em que se vive, no caso, a cidade de São Paulo com todas as suas transformações e contradições. Um dos artifícios que a arquidiocese encontra para sua ação pastoral a partir desse diálogo é a Operação Periferia,

principalmente com seus centros comunitários que se apresentam não somente como um instrumento de sacramentalização mas auxiliam no entendimento de uma ação pastoral que busca construir sujeitos eclesiais, capazes de estabelecerem diálogo com a sociedade. Por fim traremos a dimensão colegiada de seu episcopado, seja na relação com os bispos auxiliares, seja na própria organização arquidiocesana que busca organizar-se a partir de lideranças leigas e um forte senso comunitário, além de realizar periodicamente assembleias que buscam direcionar a ação eclesial a partir de prioridades percebidas pelas comunidades.

\subsection{A arquidiocese de São Paulo: uma Igreja em diálogo com a cidade}

É possível ver na organização do episcopado de Dom Paulo uma estreita sintonia com o ideal eclesiológico presente no Concílio Vaticano II. Se o Concílio busca estabelecer um diálogo com o mundo moderno, no contexto latino-americano esse diálogo acontece com as grandes cidades cada vez mais industrializadas, com processos migratórios mais intensos e uma consequente e caótica formação de regiões periféricas. Muitas outras características se fazem presentes nas grandes cidades latino-americanas, mas essas nos parecem ser mais latentes em São Paulo na segunda metade do século XX.

Se o mundo europeu vivia na segunda metade do século XX a latente necessidade de um diálogo com as consequências - ou tensões - do ideal de modernidade, a cidade de São Paulo vivia uma um 
choque do crescimento demográfico. Se hoje podemos perceber na cidade de São Paulo as maiores consequências da industrialização e da urbanização desenfreada, Dom Paulo inicia seu episcopado no momento em que a cidade vive um desordenado crescimento dos bairros da periferia e as regiões que ainda apresentavam características rurais começam a se urbanizar (MARCHINI, 2015).

A urbanização e o brusco crescimento da capital paulista irão gestar uma ação eclesial que se apresenta como proposta de diálogo com a cidade através dos movimentos populares e de uma pastoral social intensa (CONRADO, 1989, p. 19).

Ainda como bispo auxiliar responsável pela região Santana, Dom Paulo percebe que uma Igreja pastoralmente centrada na figura do presbítero apresentará pouca eficácia no diálogo com a cidade que crescia em população e território. Junto com um grupo de leigos, padres e religiosas, Dom Paulo cria a Missão do Povo de Deus (CONRADO, 1989, p. 20). Este grupo foi responsável por um diálogo estreito entre Igreja e sociedade, constituindo-se presença em hospitais, associação de bairros, grupos de rua, círculos bíblicos e centros sociais.

Mas há uma característica básica desta Missão que revela uma eclesiologia que entende a Igreja como Corpo místico de Cristo. Todos os seus membros devem estar preparados para se estabelecerem como presença da Igreja na sociedade. Há uma ampla preparação de leigos para uma fundamentada leitura bíblica. Destacamos deste grupo os biblistas Ana Flora e o frei Gorgulho. No decorrer de seu episcopado Dom Paulo levará este trabalho, que até então acontecia no Colégio Luiza de Marillac para o seminário do Ipiranga buscando assim expandi-lo para toda a arquidiocese (ARNS, 2001, p. 172).

No episcopado de Dom Paulo a valorização da figura do leigo se dá sobretudo pela participação deles nos ministérios extraordinários. A pastoral é vista não como "privilégio de alguns, mas direito e dever de todos os batizados" (CONRADO, 1989, p. 21). Em escrito da década de 1970 o próprio Dom Paulo coloca, em destaque, a missão do cristão 
consiste em assumi-la "no dia de hoje" (1972, p. 17). Assim, mais importante que o conteúdo da ação cristã, é o locus onde ela acontece. A comunidade que se deve instaurar em primazia não é o templo de pedra, mas as pessoas, chamadas pelo bispo Arns de "pedras vivas".

\subsection{A Operação Periferia: lugar de partilha e construção}

O Concílio Vaticano II tem como porta de entrada na Igreja latino-americana pela Conferência de Medellín. Junto dela há uma contextualização do Concílio na opção preferencial pelos pobres. A periferia da cidade que crescia de maneira desordenada e sem estrutura passa a ser entendida como lugar teológico privilegiado para que essa opção pelos pobres aconteça. A Igreja paulistana busca fazer com que esses anônimos da cidade passem a ser vistos e tenham sua dignidade respeitada.

Junta-se à leitura latino-americana do Vaticano II as mudanças que impactavam a cidade de São Paulo. Sua industrialização, larga produção e crescimento pastoral faziam da cidade um propício destino de migrantes que vinham sobretudo do nordeste brasileiro e habitavam a caótica periferia da cidade. Na década de 1960 a cidade recebeu treze milhões de migrantes brasileiros (DOMEZZI, 1995, p. 123).

A cidade que parece oferecer as pujanças do capitalismo que se consolida caoticamente, também apresenta os mais nocivos contrastes sociais criando uma periferia que não consegue participar das benesses supostamente prometidas àqueles que vem para a cidade. Consolida-se um contraste social na cidade de São Paulo.

Uma das maiores preocupações quanto a periferia é o acesso à moradia. Mas também há a preocupação com a educação e com o transporte (DOMEZZI, 1995, p. 163). A Operação Periferia acontecerá no intuito de auxiliar os habitantes no enfrentamento destas questões. Assim diz Dom Paulo

Sei que vocês todos já experimentaram o que eu experimentei, tantas vezes ao ir à periferia. Não tinha asfalto. Era barro. Quan- 
do chove, lama. Água e lama entram dentro de casa. Estamos dominando a terra? E as crianças? Eram centenas. (1978, p. 74)

Os centros comunitários construídos pela arquidiocese servirão de local de assistência, seja social, cultural ou religiosa para os habitantes da periferia. Muitos migrantes nordestinos utilizam do espaço dos Centros Comunitários para a realização de festas típicas. Segundo o próprio Dom Paulo, no ano 1975 a população da cidade de São Paulo era de 7.768.668 habitantes, mas destes, 3.114.268 não eram nela nascidos (ARNS, 1980, p. 32). Mas estes Centros também são utilizados para reuniões das associações de bairros e para a celebração de missas e essa era a orientação dada pela própria arquidiocese, impulsionada por Puebla (ARNS, 1980, p. 36).

Monsenhor Conrado, ao comentar as experiências na periferia da cidade, diz:

Dom Paulo percebia que não bastava uma ação pastoral bem realizada. Era necessário sobretudo, verificar com que objetivos ela se desenvolvia e se a Igreja estava respondendo à altura aos desafios emergentes na cidade, se o povo participava, sobretudo, se as comunidades sentiam-se como sujeitos ativos na pastoral.

O princípio do leigo como sujeito eclesial se concretiza na Operação periferia. Seus objetivos consistiam em:

- criar entre os agentes de pastoral um espírito verdadeiramente missionário e ir em busca do povo;

- criar e coordenar recursos humanos e materiais em todos os níveis e setores;

- descobrir e treinar lideranças locais e animadores de comunidade que ajudassem o povo, através da organização, à luz da Palavra de Deus, ser sujeito de sua libertação.

Fato emblemático é a venda do palácio episcopal, Palácio Pio XII, para a construção de centenas de centros comunitários na periferia de São Paulo. Segundo pesquisa de Domezzi, foram adquiridos 129 
imóveis nas várias regiões da arquidiocese num total de 80.421,35 metros quadrados (1985, p. 184). Em 1979 a arquidiocese conta com quinhentos e seis Centros Comunitários. Isso enquanto o número de paróquias totalizava 385 .

O CEBRAP (Centro Brasileiro de Análise e Planejamento) forneceu uma análise social da capital paulistana através do livro São Paulo 1975 - crescimento e pobreza que serviu de subsídio para muitas comunidades da periferia da cidade. Segundo Maria Domezzi, o sucesso da Operação Periferia se deve à formação de lideranças nas comunidades, que estavam no meio dos pobres, das comunidades (1985, p. 121).

A Operação Periferia não apresentou formatações ou padronizações de sua implementação. A ideia era deixar espaço para que cada comunidade encontrasse seus próprios caminhos a partir de necessidades concretas.

\subsection{Um clero e as assembleias diocesanas: uma Igreja colegiada}

Uma diocese se organiza a partir da figura do bispo. Sua ausência ou mesmo sua transferência acarreta em várias implicações práticas para a vida da porção do Povo de Deus presente no território diocesano. Dom Paulo está longe de quebrar com essa estrutura, mas dá a ela mais agilidade. Uma das mudanças é a subdivisão pastoral da arquidiocese.

Cada bispo passa a ser responsável de maneira mais assertiva por sua região. Alguns bispos também recebem outras incumbências em nível mais amplo. Dom Joel Catapan, bispo da região Santana, será responsável pela pastoral vocacional e pela juventude e Dom Angélico Bernardino, então bispo da região de São Miguel, será responsável pela pastoral Operária. A função do arcebispo passa a ser administrar essa colegialidade com reuniões mensais além de um estreito acompanhamento de ações pastorais específicas (ALMEIDA, 1989, p. 45). 
A colegialidade chega as comunidades através de seu mais concreto fruto: os planos pastorais. Grande parte do clero é formado nesse contexto e consegue levar às comunidades o ideal de uma Igreja de comunhão e participação.

Bispos auxiliares formaram o "Colégio Episcopal”, com Dom Paulo Evaristo, apóstolo da comunhão e participação, à frente! Bispos formando grupo de irmãos-amigos, felizes à frente em suas Regiões Episcopais, agarrando, colegialmente, toda a Arquidiocese, permanecendo em seus postos por longos anos, como sacerdotes, profetas, sentindo o "cheiro das ovelhas", como afirma, agora, o iluminado Papa Francisco. Bispos fazendo um corpo com presbíteros, religiosas, religiosos, leigos e leigas, anunciando, com alegria, por todos os cantos e recantos da metrópole o amor de Deus Pai que no vigor do Espírito Santo, nos envia seu Filho Jesus em salvação, libertação. (BERNARDINO, 2015, p. 34)

Assim partilha algum

aqui em São Paulo, nós precisamos idealizar um plano no qual a Igreja se mantenha numa unidade onde os Bispos não trabalhem separadamente. Um Colegiado deveria nortear todas as ações da Igreja, mas sem desrespeitar as peculiaridades de cada região. Eu quero e preciso de um grupo de Bispos que formem comigo este Colegiado. Não os quero simplesmente para me ajudarem - para isso posso contar com os leigos que ajudam muito bem-, eu quero a presença do Bispo lá na periferia onde o Arcebispo não pode estar o tempo todo porque tem inúmeras atividades. Mas estará presente com e por meio de seus Bispos, irmãos no episcopado. (QUEIRÓZ, 2015, p. 48)

Momentos celebrativos como a festa de Corpus Christi, celebrada sempre na praça da Sé, marcam a unidade arquidiocesana. E em um desses momentos fica evidente como a divisão territorial da arquidiocese, em 1978, traz algum impacto na vivência de um episcopado colegiado. Pouco antes da festa acontece a criação das dioceses de Osasco, Santo Amaro, Campo Limpo e São Miguel Paulista. Essa 
última é efusivamente acolhida por Dom Paulo ao chegar na praça da Sé dando sinais de seu descontentamento mas de sua obediência diante do acontecido.

Mas o colegiado de Dom Paulo não acontecia unicamente com o clero, mas também com o povo. Os leigos são preparados para viverem a liderança em suas comunidades. Muitas congregações religiosas formam comunidades na periferia da cidade. Ainda como bispo auxiliar responsável pela Região Norte paulistana, suscita 0 Movimento por um Mundo Melhor, responsável pela formação de lideranças leigas a partir de formação bíblica (ALTEMEYER, 2015, p. 14). As lideranças leigas presentes no episcopado de Dom Paulo revelam esta perspectiva de participação.

\section{Conclusão}

Dom Paulo mostra grande lucides não só no que se diz respeito às necessidades pastorais do século XX, mas de sua própria teologia prática, que serve de substrato para essa ação e diálogo, como mostra também uma boa relação com intelectuais, sejam cristãos-católicos ou não, para conversar sobre as situações referentes à sociedade brasileira e paulistana. Para ele a Igreja deve se organizar, apesar de não ser uma empresa. Ela deve revelar a unidade em seu clero que não deve ser uniformizado, mas unido na pessoa de Jesus (1972, pp. 18-19). E por fim há algo de muito atual no pensamento do cardeal Arns. A Igreja não é sociedade de consumo, mas de coparticipação (1972, pp. 19-20). Num momento histórico onde a participação religiosa assume cada vez mais traços de consumo e busca às duras penas garantir a pertença comunitária, Dom Paulo aponta para a comunidade como local de partilha.

A evangelização de Dom Arns é concebida como Missão do Povo de Deus em que todos precisam ser ouvidos em suas Assembleias Diocesanas, provocando o este Povo a seguir os sinais dos tempos e assumir a opção pelos pobres com sua Operação periferia, para 
exatamente descobrir que Deus estava escondido [latens deitas] na periferia e onde o Reino de Deus se fazia mais necessário. Inevitavelmente, ao assumir a opção pelos pobres e se tornar porta voz dos Direitos Humanos na Arquidiocese de São Paulo se tornou interlocutor de muitos movimentos. Vale dizer que a teologia prática de Dom Paulo Arns tinha como categoria de discernimento os sinais do Reino de Deus, e com isso estabelecia seu diálogo, sabendo distinguir, mais que o traumatizado olhar polonês, que a linguagem e práxis marxista na Europa era cerceadora de liberdade, ao passo que na América Latina era na época um dos poucos, senão o único espaço de pensar livremente, contra dos generais católicos da ditadura militar da primeira metade do século XX. Dom Paulo parecia entender sua catolicidade a partir da universalidade do Reino de Deus, e despindo-se de qualquer autoreferencialidade eclesial é que ganhou o respeito dentro e fora da Igreja, por seu Cristianismo moderno e ao mesmo tempo, mais original que criativa e significativamente expandiu a presença do Reino de Deus na Arquidiocese de São Paulo.

Os tempos atuais se apresentam junto com profundas mudanças. A Igreja que antes era importante organizador da vida comunitária e social agora se torna mais um entre os tantos elementos. Segundo o próprio Dom Paulo há uma crise na Igreja. Mas essa crise Seria essa crise benéfica ou não? Tomamos a liberdade de, inspirados nos referenciais de diálogo do cardeal Arns (1972, pp. 283-284) não nos lamentarmos pelo que se foi, mas perceber que, estando livre das amarras do poder que estão atreladas às organizações sociais, a Igreja pode se dedicar àquilo que realmente lhe é imprescindível: a construção do Reino.

\section{Bibliografia}

ALMEIDA, Luciano Mendes de. Colegialidade episcopal: uma vivência bem-sucedida em São Paulo. In: RIBEIRO, Helcio (coord.). Paulo Eva- 
risto Arns: cardeal da esperança e pastor da Igreja de São Paulo. São Paulo: Paulinas, 1989. pp. 44-46.

ALTEMEYER Jr. Fernando. Dom Paulo, cardeal da esperança: origens, horizontes, segredos e sonhos. In: PROFESSOR WALDIR; PADRE TICÃO (orgs). Dom Paulo Evaristo Arns: cardeal pastor das periferias, dos pobres e da justiça. São Paulo: Casa da Terceira Idade Tereza Bugolim, 2015. pp. 13-26.

ARNS, Paulo Evaristo. Comunidade: união e ação. São Paulo: Paulinas, 1972.

ARNS, Paulo Evaristo. Da esperança à utopia: testemunho de uma vida. 2 ed. Rio de Janeiro: Sextante, 2001.

ARNS, Paulo Evaristo. Discutindo o papel da igreja. São Paulo: Loyola, 1980.

ARNS, Paulo Evaristo. Presença e força do cristão. São Paulo: Loyola, 1978.

AURELII AUGUSTINI OPERA OMNIA. Nuova Biblioteca Agostiniana. Roma: Città Nuova Editrice.

BERNARDINO, Angélico Sândalo. Grande profeta surgiu entre nós. In: PROFESSOR WALDIR; PADRE TICÃO (orgs). Dom Paulo Evaristo Arns: cardeal pastor das periferias, dos pobres e da justiça. São Paulo: Casa da Terceira Idade Tereza Bugolim, 2015. pp. 34-35.

BÍBLIA SACRA. Utriusque Testamenti: Editio Hebraica et Graeca. Deutsche Bibelgeselschaft: Stuttgart, 1993.

CHENU, Marie-Dominique. La Teologia nel XII Secolo. Milano: Jaca Book, 1983.

CONRADO, Sérgio. D. Paulo, pastor da grande cidade. In: RIBEIRO, Helcio (coord.). Paulo Evaristo Arns: cardeal da esperança e pastor da Igreja de São Paulo. São Paulo: Paulinas, 1989. pp. 19-34.

DOMEZZI, Maria Cecília. Do corpo cintilante ao corpo torturado: uma igreja em operação periferia. São Paulo: Paulus, 1995.

HÜNERMANN. Peter. verbete Reino de Deus In LACOSTE, J. Dicionário Crítico de Teologia. São Paulo: Paulinas/Edições Loyola, 2004, p. 1505-1506. 
JAEGER, Werner. Cristianismo primitivo e Paideia grega. Lisboa: Edições 70, 1991.

JOURNEL, Rouët M. J. Enchiridion Patristicum. Herder Typographus Editor Pontificius: Friburg Brisgoviae, 1913.

MELO, Antonio Alves. A Evangelização no Brasil - Dimensões teológicas e desafios pastorais: O debate teológico e eclesial (1952-1995). Tesi Gregoriana: Serie teologia. Volume 16. Editrice Pontificia Uniersità Gregoriana: Roma, 1996.

METZ, Jean Baptist. La foi dans l'histoire et dans la société: Essai d'une Théologie Fondamentale Pratique. Col. Cogitatio Fidei, n. 99. Paris: Cerf, 1999.

PEGORARO, José. Um só povo, muitos pastores? A divisão da arquidiocese de São Paulo. In: RIBEIRO, Helcio (coord.). Paulo Evaristo Arns: cardeal da esperança e pastor da Igreja de São Paulo. São Paulo: Paulinas, 1989. pp. 35-43.

QUEIRÓZ, Antonio Celso de. Dom Paulo e os bispos de São Paulo. In: PROFESSOR WALDIR; PADRE TICÃO (orgs). Dom Paulo Evaristo Arns: cardeal pastor das periferias, dos pobres e da justiça. São Paulo: Casa da Terceira Idade Tereza Bugolim, 2015. pp. 45-51.

RAMALHO, Jefferson. Eusebio e Constantino: o início de uma Igreja Imperialista. São Paulo: Fonte Editorial, 2013.

SYDOW, Evanize; FERRI, Marilda. Dom Paulo Evaristo Arns: um homem amado e perseguido. Petrópolis: Vozes, 1999.

VAZ, Henrique. C. Lima. Raízes da Modernidade: Escritos de Filosofia, VII. São Paulo: Edições Loyola, 2002. (Coleção Filosofia).

VILLAS BOAS, Alex. Misericórdia e Alteridade na perspectiva teológica do Papa Francisco. Tese de Livre Docência em Ética e Linguagem Teológica (233fls). Programa de Estudos Pós-Graduados em Teologia da Pontifícia Universidade Católica de São Paulo (PUC SP), 2017.

VILLAS BOAS, A. Teologia em diálogo com a Literatura: origem e tarefa poética da teoogia. São Paulo: Paulus, 2016.

Recebido em: 27/07/2017

Aprovado em: 20/10/2017 